Л. Р. Шостакович-Корецька, В. В. Маврутенков, А. В. Чергінець, І. В. Будаєва, К. Ю. Литвин, М. С. Суременко, Т. А. Гайдук, О. М. Якуніна, В. П. Дядик ДЗ “Дніпропетровська медична академія МОЗ України”, м. Дніпро

\title{
ІННОВАЦІЙНІ МЕТОДИ НАВЧАННЯ У ПІДГОТОВЦІ УЧАСНИКІВ ПРОФЕСІЙНО-ОРІЄНТОВАНИХ ОЛІМПІАД
}

\author{
L. R. Shostakovich-Koretskaya, V. V. Mavrutenkov, A. V. Cherhinets', I. V. Budaieva, \\ K. Y. Lytvyn, M. S. Suremenko, T. A. Gayduk, O. M. Yakunina, V. P. Diadyk \\ Dnipropetrovsk Medical Academy of Ministry of Healthcare of Ukraine, Dnipro \\ INNOVATIVE TEACHING METHODS FOR THE TRAINING OF \\ PROFESSIONALLY ORIENTED OLYMPIAD PARTICIPANTS
}

\begin{abstract}
Мета роботи - представити власний досвід застосування різних варіантів імітаційної технології при підготовці учасників студентських олімпіад з професійного циклу “Інфекційні хвороби”.

Основна частина. Розглянуто інноваційні методики викладання курсу інфекційних хвороб у вищій медичній школі, впроваджені авторами з метою підвищення ефективності навчання. Докладно висвітлені питання проведення медичних студентських олімпіад з навчальних дисциплін професійного циклу. Проаналізовано власний досвід застосування варіантів імітаційної технології: методів case-study, рольових ігор, “мозкової атаки”.

За останні 5 років на базі студентського наукового гуртка кафедри інфекційних хвороб ДЗ “Дніпропетровська медична академя MO3 України” пройшла підготовка 53 студентів-бакалаврів. 3 них 14 студентів брали безпосередню участь у змаганнях на щорічних всеукраїнських олімпіадах з інфекційних хвороб. Результатом плідної підготовки стало здобуття 6 призових місць в індивідуальних змаганнях і 8 призових місць у командних змаганнях.

Висновки. На відміну від традиційних форм навчання, впровадження активних методів, на прикладі підготовки до олімпіади, дозволяє формувати професійні вміння і діяльну реалізацію набутих знань, моделювати цілісний зміст самостійної роботи, при цьому зміщується центр значущості з процесу передачі, переробки і засвоєння інформації на самостійну творчу діяльність. Саме такий підхід може дозволити студенту набути високих результатів як під час змагання на студентській олімпіаді, так i надалі у практичній діяльності при формуванні особистості конкурентоспроможного фахівця.
\end{abstract}

Ключові слова: вища медична освіта; інновації; активні методи навчання; професійно-орієнтовані олімпіади.

The aim of the work - to present our own experience in using different forms of simulation technology in preparing professionally oriented olympiad participants on the infectious diseases course.

The main body. Innovative methods of teaching the course of infectious diseases in the higher medical school introduced by the authors for the purpose of increasing the efficiency of education are considered. The issues of conducting medical student's olympiads on professional disciplines are elucidated in detail. The authors' own experience of using the variants of imitation technology (case-study methods, role-playing games, "brain attack") has been analyzed.

Over the past five years, 53 undergraduate students have been teached on the basis of a student's scientific course at the Department of Infectious Diseases in Dnipropetrovsk Medical Academy. Of these, 14 students directly participated in professionally oriented Olympiad at the annual Ukrainian Olympiads on infectious diseases. The result of productive training was taking of six prize-places in individual competitions and eight prize-places in team competitions.

Conclusions. Unlike the traditional forms of study, the implementation of active methods, on example of training for an Olympiad, allows to form the professional skills and active realization of acquired knowledge, model the integral content of individual work, thus shifting the center of significance from the process of transferring, processing and assimilating information to independent creative activity. Such an approach can allow a student to achieve high results both during the competition at the student's olympiad, and in the future in the practical activity of forming the person of a competitive specialist.

Key words: higher medical education; innovation; active teaching methods; professionally oriented olympiad.

Вступ. Сучасна вища освіта, остаточною метою якої є підготовка висококваліфікованого і конкурентоспроможного фахівця, складається не тільки з процесу навчання, як оволодіння студентом пев- ною базою теоретичних знань, а також і набуття ним практичних умінь, щодо формування творчомислячої особистості, здатної приймати відповідальні й оптимальні рішення в конкретних та не-

(ㄱ Л. Р. Шостакович-Корецька, В. В. Маврутенков, А. В. Чергінець та ін. 
стандартних ситуаціях. У зв’язку з цим останніми роками активно впроваджуються різні інноваційні методики навчання, спрямовані на саморозкриття особистості студента, активне засвоєння різних способів пізнавальної діяльності з кінцевою орієнтацією на формування не тільки “людини, що пізнає”, а й “людини, що діє”.

Мета роботи - впровадження інноваційних методів навчання у комплексний процес підготовки майбутнього лікаря-фахівця терапевтичного профілю на прикладі підготовки до фахових олімпіад.

Основна частина. Інноваційне навчання вимагає активної творчої діяльності як з боку студента, так і викладача. Сучасний викладач повинен бути орієнтований, більшою мірою, не стільки на передавання загальних знань і умінь, скільки на створення умов, у яких студент може отримувати нову інформацію, формувати власні ідеї, бачити проблему і, головне, визначати ефективні шляхи її вирішення.

Однією з педагогічних інновацій є проведення олімпіад з навчальних дисциплін професійного циклу, що сприяє не тільки підвищенню інтересу до вивчення окремих предметів, а й ефективній трансформації теоретичного компонента навчання у професійно-практичний. Одним із таких методів підготовки фахівця можна вважати олімпіадний рух, який є окремою та поглибленою формою навчання, що об’єднує основні переваги сучасних методів засвоєння інформації (активних, контекстних, проблемних, когнітивних, тих, що розвиваються, диференційованих та індивідуальних, багаторівневих і безперервних, інноваційних та компетентнісних). Більш того, олімпіада має систему конкурсних (зазвичай нестандартних) індивідуальних змагань студентів, що впливає на формування в них конкурентоспроможності [1].

Загальноприйнято проводити щорічні медичні олімпіади в два етапи: вишівський та всеукраїнський. Основний контингент олімпійців з дисциплін “Інфекційні хвороби” та “Дитячі інфекції” складають студенти 5-го та 6-го курсів бакалаврату. Традиційно програми олімпіад складаються 3 майстер-класів з невідкладної медичної допомоги, диференційної діагностики інфекційних та соматичних захворювань, диференційованого й аргументованого вибору обстеження та терапії.

Професійна діяльність інфекціоністів, а особливо інфекціоністів дитячих, меншою мірою, порівняно, наприклад, з хірургами, стоматологами, анестезіологами, акушерами-гінекологами, передбачає, здебільшого, терапевтичні навички. Тому при проведенні олімпіади використання симуляційного обладнання є обмеженим, а студент-олімпієць діє за принципом давнього латинського прислів’я “Veni, vidi, vici". Через це елементи імітації реальної практичної діяльності лікаря-інфекціоніста та лікаря інфекціоніста дитячого на олімпіадах з інфекційних хвороб для оцінки професійної компетентності використовуються індивідуальні портфоліо, які містять добірку лабораторних та інструментальних досліджень, фотознімків хворих на інфекційну патологію, клінічні ситуаційні задачі. Оцінка практичних навичок клінічного огляду проводиться під час клінічного розбору реального хворого у присутності суддівської комісії.

Студентська олімпіада включає три етапи: підготовку учасників до виступу, проведення самої олімпіади та аналіз діяльності учасників. Для підготовчого етапу необхідна методична система, яка здатна забезпечити засвоєння студентом широкого кола завдань. Зокрема, ця система підготовки включає навчання таких навичок і вмінь, як [1]:

- екстраполяція фундаментальних знань в інфектологію;

- використовування міжфахових зв’язків;

- самостійність у пізнавальній діяльності;

- вміння вирішувати завдання підвищеного рівня складності на підставі комплексного аналізу та узагальнення даних.

Спираючись на дослідження Х. Е. Майхнера, який відзначав, що при пасивному сприйнятті людина запам’ ятовує 10 \% прочитаного, 20 \% почутого, 30 \% побаченого і 50 \% побаченого і почутого, а при активному сприйнятті - зберігає в пам’яті 80 \% того, що говорила сама, і 90 \% того, що робила або створювала самостійно, можна зробити висновок, що активні методи навчання значно покращують засвоєння матеріалу і сприяють його ідентифікації та подальшій цілеспрямованій практичній реалізації [2].

Сьогодні, серед сучасних інноваційних технологій широкого застосування набув метод case-study. Витоки цього методу походять 3 античності, але сучасного вдосконалення метод набув наприкінці XIX століття в Гарвардському університеті [3, 4]. У медицині кейси як регламентоване навчання почали використовуватися з 1985 р. у Медичній школі Гарварда (Harvard Medical School) [5]. Згодом фахівці відзначали необхідність освоєння нових навчальних технологій, основаних на активних методах навчання (Міжнародна конференція Російської асоціації бізнес-освіти (РАБО), листопад 
1999 р.; м. Хургада, Єгипет) [2]. Сутність цього методу полягає в проблемному викладенні ситуації (єдиний інформаційний комплекс) на основі фактів із реального життя з подальшою організацією самостійної роботи студента.

Розрізняють “мертві” і “живі” кейси. До “мертвих” кейсів відносять ті кейси, в яких міститься вся необхідна для аналізу інформація. Вилучення частини інформації вносить деяке протиріччя й “оживляє” кейс, що провокує студентів на пошук відсутньої інформації для подальшого аналізу. Кейси розв'язуються в умовах обмеженого часу [5].

Основні переваги кейса включають три складові: 1) практичну спрямованість, яка компенсує виключно академічну освіту; 2) інтерактивний формат, який забезпечує високу емоційну складову й активну участь усіх учнів; 3) розробку ряду ефективних рішень, але пошук оптимального; 4) набуття конкретних практичних навичок, які виявляються вкрай необхідними в реальному робочому процесі [5].

Розв'язання кейсів складається з декількох кроків: 1) дослідження запропонованої ситуації (кейса); 2) збору та аналізу інформації, якої бракує; 3) обговорення можливих варіантів вирішення проблеми; 4) розробки найкращого рішення $[5,6]$.

Кейси розрізняються за форматом використання і рівнем складності $[3,5,6]$.

За форматом використання виділяють:

- виконавчі (Executive) кейси (1-2 стор. і менше). Учасники знайомляться з кейсом безпосередньо під час заходу і вирішують його індивідуально або у форматі обговорення з модератором. Такі кейси використовуються в якості ілюстрації теоретичного матеріалу або для перевірки конкретних вузьких навичок;

- тематичні кейси (3-5 стор.). Призначені для розбору на навчальному занятті і загальній дискусії, іноді передбачається коротка попередня підготовка учасників;

- гарвардські кейси (в середньому 20-25 стор.). Передбачають самостійну командну роботу протягом декількох днів і презентацію рішення.

За рівнем складності кейси можуть бути:

- структурованими (highly structured), які включають до себе мінімальну кількість додаткової інформації;

- “маленькими начерками” (short vignetts), що ознайомлюють тільки 3 ключовими поняттями, включають 2-3 стор. додатків;

- великими неструктурованими (long unstructured cases), які є найскладнішими. Учасникам потрібно впоратися з великим обсягом слабо структурованих даних.
Робота з медичними кейсами відрізняється від бізнес-кейсів своїм форматом [5]. Студенти-медики традиційно працюють невеликими групами, по 6-8 осіб. Кейс складається з 5-6 частин, у яких наводять інформацію про початковий стан пацієнта і симптоми хвороби, результати первинного огляду, результати лабораторних досліджень, висновок фахівців, можливо - призначене лікування, реакція пацієнта на це лікування і подальший перебіг захворювання. В ході обговорення від студента не вимагається пропонувати готові рішення. Мета полягає в тому, щоб поставити подальші питання, висунути гіпотези, виявити прогалини в знаннях. Розбір кейсів можна проводити індивідуально зі студентом або в групах. Групове рішення кейсів передбачає проведення навчальних інтерактивних імітаційних ігор. Розрізняють ділові ігри (метод інциденту) і рольові ігри (розігрування ситуації в ролях) [2].

За останні 5 років на базі студентського наукового гуртка кафедри інфекційних хвороб ДЗ “Дніпропетровська медична академія МО3 України” пройшла підготовка 53 студентів-бакалаврів. 3 них 14 студентів брали безпосередню участь у змаганнях на щорічних всеукраїнських олімпіадах з інфекційних хвороб. Результатом плідної підготовки з'явилося здобуття 6 призових місць в індивідуальних змаганнях і 8 призових місць у командних змаганнях.

Як показує власний досвід, на заняттях із підготовки студентів до олімпіади найкращим $є$ метод рольових ігор.

Нами застосовувалася наступна методика гри. Ведучий - викладач, починає гру з оголошення початкової лікарської ситуації і призначає першого студента, наприклад, на роль матері хворого, яка викликає дільничного лікаря - іншого студента; той, у свою чергу, обирає лікаря швидкої допомоги і т. д. Доцільність всіх прийнятих студентами рішень обов'язково обгрунтовується вголос. Під час гри викладач, а краще - студент-експерт, може вводити різну додаткову інформацію, що ускладнює ситуацію (зміна стану хворого, відсутність лікарських препаратів і їх адекватна заміна тощо). Додаткова інформація може бути також поведінкового характеру, наприклад, відмова хворого від госпіталізації, скарга хворого або його родичів та ін. У цих випадках гра дає можливість випробувати свою здатність спілкування в різних ситуаціях і оцінити себе. Підведення підсумків гри проводиться студентами-експертами: оцінюються правильні і помилкові рішення всіх учасників гри. Кожен зі студентів може викласти свою точку зору на ситуа- 
ції, які програвались, визначити оптимальність їх реалізації.

Також одним із варіантів імітаційної технології, який часто використовується нами на практиці, є метод “мозкової атаки”. Наш досвід показує, що цей метод відмінно працює в умовах обмеженого часу. При цьому групі дається ситуація або питання, що свідомо несе протиріччя або альтернативу. Протягом декількох хвилин члени групи говорять на цю тему все, що спадає їм на думку, і все це фіксується на папері. У цей час не діють заборони і не даються ніякі оцінки; учасники мають можливість пізніше розібрати пропозиції, висловити незгоду й обговорити всі запропоновані ідеї. “Мозкова атака” може продемонструвати, що знають студенти; в ході її можуть бути запропоновані ідеї, здатні вирішити проблему, створена структура обміну поглядами на загальний досвід і висловлені побажання студентів. Важливою перевагою імітаційних методів є їх орієнтація на тренінгові функції: учні приймають власні рішення, при цьому очевидна спрямованість на формування навичок професійної поведінки в колективі, вміння аналізувати характер міжособистісних взаємин.

Практично для всіх закордонних шкіл характерно використання імітаційного моделювання у тій чи

\section{Список літератури}

1. Руднев В. В. Олимпиада как один из способов инновационной деятельности обучающихся в вузе / В. В. Руднев, Л.Н.Аксенова, М.Л.Хасанова // Международный научный журнал “Инновационная наука”. - 2017. - № 10. - С. 77-79.

2. Змиевская Е. В. Деловая игра как метод активного обучения / Е. В. Змиевская [Электронный ресурс]. URL : http://www.superinf.ru/view_helpstud.php?id=1076.

3. Forman J. The genre system of the Harvard case method/ J. Forman // Journal of Business and Technical Communication. - 1999. - Vol. 13, No.10. - P. 373-400.

4. Garvin D. Making the Case: Professional education for the world of practice / D. Garvin // Harvard Magazine. 2003. - Vol. 106, No. 1.

5. Введение в кейс-метод: что такое кейсы и зачем они нужны [Электронный ресурс]. - URL : http:// changellenge.com/chto-takoe-keysy/.

\section{References}

1. Rudnev, V.V., Aksenova, L.N., \& Khasanova, M.L. (2017). Olimpiada kak odin iz sposobov innovatsionnoy deyatelnosti obuchayushchikhsya v vuze [Olympics as a way of students' innovative activity in high school]. Mezhdunarodnyy nauchnyy zhurnal "Innovatsionnaya nauka"- іншій його формі [7-9]. Медичне співтовариство, особливо його академічна частина, є надзвичайно прогресивним середовищем, чуйним до змін і новацій у медичній науці і практиці, але, з іншого боку, досить консервативним щодо нових методів навчання майбутніх лікарів. Зміна парадигми навчання на парадигму вчення вимагає від викладачів медичного ВНЗ не тільки знання потенційних можливостей активних та інтерактивних методів навчання, а й компетенції, пов’язаної з проектуванням і впровадженням їх у навчальний процес. Очевидно, що одним із перших кроків на цьому шляху має бути осмислення змісту дисципліни з точки зору потенціалу використання активних методів.

Висновки. Таким чином, на відміну від традиційних форм навчання, впровадження активних методів, на прикладі підготовки до олімпіади, дозволяє формувати професійні вміння і діяльну реалізацію набутих знань, моделювати цілісний зміст самостійної роботи, при цьому зміщується центр значущості з процесу передачі, переробки і засвоєння інформації на самостійну творчу діяльність. Саме такий підхід може дозволити студенту набути високих результатів під час змагання на студентській олімпіаді, так і надалі у практичній діяльності при формуванні особистості конкурентоспроможного фахівця.

6. Blagg D. Chris Christensen: Legend of the Classroom, April 16, 2008 [Electronic resource] / D. Blagg. - URL : https://hbswk.hbs.edu/item/chris-christensen-legend-of-theclassroom (Harvard Business School Working Knowledge).

7. Тренинг для тренеров. Методы. Рекомендации. Street Law, Inc. 2000.

8. Cooper J. B. A brief history of the development of mannequin simulators for clinical education and training / J. B. Cooper, V. R. Taqueti // Postgrad. Med. J. - 2008. No. 84 (997). - P. 563-570.

9. Clinical simulation: importance to the internal medicine educational mission / P. E. Ogden, L. S. Cobbs, Howell [et al.] // Am. J. Med. - 2007. - No. 120 (9). - P. 820-824.

International Scientific Journal “Innovative Science”, 10, 77-79 [in Russian].

2. Zmiyevskaya, E.V. (2011). Delovaya igra kak metod aktivnogo obucheniya [Business game as a method of active learning]. - Retrieved from: http://www.superinf.ru/ 
view_helpstud.php?id=1076 (accessed 13 April 2018). [in Russian].

3. Forman, J. (1999). The genre system of the Harvard case method. Journal of Business and Technical Communication, 13 (10), 373-400.

4. Garvin, D. (2003). Making the Case: Professional education for the world of practice. Harvard Magazine, 106 (1).

5. (2016). Vvedenie v keys-metod: chto takoe keysy i zachem oni nuzhny [Introduction to the case-study method: what are cases and why they are needed]. - Retrieved from: http://changellenge.com/chto-takoe-keysy/ [in Russian].

6. Blagg, D. (2008). Chris Christensen: Legend of the Classroom. - Retrieved from: https://hbswk.hbs.edu/ item/chris-christensen-legend-of-the-classroom (Harvard Business School Working Knowledge).

7. (2000). Trening dlya trenerov. Metody. Rekomendatsii [Training for trainers. Methods. Recommendations.] Street Law, Inc. [in Russian].

8. Cooper, J.B., \& Taqueti, V.R. (2008). A brief history of the development of mannequin simulators for clinical education and training. Postgrad. Med. J., 84 (997), 563-570.

9. Ogden, P.E., Cobbs, L.S., \& Howell, M.R. (2007). Clinical simulation: importance to the internal medicine educational mission. Am. J. Med., 120 (9), 820-824.

Електронна адреса для листування: k-lytvyn@ukr.net 